\title{
Legal aspects of \\ care in the community
}


Also by Bridgit Dimond

Legal Aspects of Nursing, 2nd edition

Legal Aspects of Midwifery

Patients' Rights, Responsibilities and the Nurse

Accountability and the Nurse (distance learning pack)

Mental Health Law for Nurses (with Frances Barker)

Legal Aspects of Child Health Care

Legal Aspects of Health Care 


\section{Legal aspects of}

care in the community

Bridgit Dimond

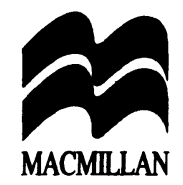


All rights reserved. No reproduction, copy or transmission of this publication may be made without written permission.

No paragraph of this publication may be reproduced, copied or transmitted save with written permission or in accordance with the provisions of the Copyright, Designs and Patents Act 1988, or under the terms of any licence permitting limited copying issued by the Copyright Licensing Agency, 90 Tottenham Court Road, London W1P 9HE.

Any person who does any unauthorised act in relation to this publication may be liable to criminal prosecution and civil claims for damages.

The author has asserted her rights to be identified as the author of this work in accordance with the Copyright, Designs and Patents Act 1988.

First published 1997 by

MACMILLAN PRESS LTD

Houndmills, Basingstoke, Hampshire RG21 6XS

and London

Companies and representatives

throughout the world

ISBN 978-0-333-53820-3 ISBN 978-1-349-25161-2 (eBook)

DOI 10.1007/978-1-349-25161-2

A catalogue record for this book is available from the British Library.

This book is printed on paper suitable for recycling and made from fully managed and sustained forest sources.

$\begin{array}{rrrrrrrrrr}10 & 9 & 8 & 7 & 6 & 5 & 4 & 3 & 2 & 1 \\ 06 & 05 & 04 & 03 & 02 & 01 & 00 & 99 & 98 & 97\end{array}$


In memory of Stuart 


\section{Contents}

Preface

Acknowledgements

Abbreviations

$\mathbf{x}$

xiii

xiv

1. Introduction 1

Section A: Clients 7

2. Clients and community care 9

3. Consent to treatment 30

4. Entry and removal from premises and 61

5. Confidentiality 82

6. Access to health records 92

References for Section A 106

$\begin{array}{ll}\text { Section B: Professionals } & 109\end{array}$

Part 1: Professional liability 111

7. General principles of accountability 112

8. Special situations 129

9. Health and safety: 1

10. Health and safety: 2

11. Record keeping and reports 197

12. Medicinal products in the community 205

References for Section B Part 1

Part 2: Specific professionals and individuals 219

13. Social workers: care managers and key workers 221

14. Community nurses 231

15. Community psychiatric nurses 241

16. Specialist nurses 252 
viii $\cdot$ CONTENTS

17. Health visitors 267

18. Practice nurses 276

19. Professions supplementary to medicine 287

20. Private practitioners 296

21. Volunteers 308

22. Carers 318

References for Section B Part 2

Section C: The Statutory Authorities and other organisations

23. Health Authorities and Trusts 335

24. GP Fund-holding practices 358

25. Local authorities 378

26. The independent sector 411

27. Enforcement of statutory duties 425

References for Section C 457

Section D: Accommodation and community care 459

28. Local authorities and the provision of accommodation

29. Registered homes 1: residential homes 480

30. Registered homes 2: nursing and mental nursing homes

31. Registered homes 3: tribunals and complaints $\quad 514$

32. Housing corporations and associations and planning concerns $\quad 524$

References for Section D 540

Section E: Finances and the client 543

33. Charges and income 545

34. The management of finance and handling
clients' property

References for Section E $\quad 579$

35. The future 577

Appendix 1: Extracts from LAC(93)10 582

Appendix 2: Consent forms 592

Appendix 3: Specialist Bibliographies $\quad 596$

Appendix 4: HSG(95)39 597

Appendix 5: HSG(95)41 607

Appendix 6: Summary of SI 1996 No. 706

Appendix 7: Useful addresses $\quad 617$ 
CONTENTS $\cdot$ ix

Glossary

624

Bibliography

627

Table of Cases

629

Table of Legislation

632

Index

643 


\section{Preface}

Community care has always existed. Once it was provided on a formal basis as outdoor relief by the monasteries, later in history state support was provided through the Poor Law. Recently the term has been used to contrast with the care provided in institutions especially for the old, mentally ill and mentally impaired. The Community Care Plans published in 1963, which followed the Hospital Plans of 1962 overseen by the then Minister of Health Enoch Powell, envisaged that the large institutions provided by the National Health Service for long-stay patients would be reduced in size - even razed to the ground - and community care would take their place. The plans have been a long time in the implementing, each successive Government emphasising the priority which should be given to care in the community, and gradually the number of institutional places has been reduced with varying degrees of community provision being made. Important legal changes were made in 1983 enabling joint financing and funding to take place between health and local authorities to facilitate the discharge of patients.

The second Griffiths Report and the white paper, Caring for People, followed by the National Health Service and Community Care Act 1990 have made major changes in the responsibility for financing community care and shifted more responsibility from the health service to the local authorities. For the first time a statutory definition was given to community care which is set out in Chapter 2.

This book is specifically concerned with the health aspects of community care and seeks to identify some of the legal problems faced by the various professionals who work in the community caring for people. It is focused on five areas: 
A. The rights of the client in relation to care, powers of entry and removal from premises, consent and confidentiality.

B. The duties and responsibilities of the many professionals providing care, initially in relation to their accountability and professional liability and then in relation to health and safety concerns (specific chapters deal with individual professional groups, volunteers and carers).

C. The statutory bodies and other organisations involved in the provision of care, also considering enforcement provisions.

D. The legal issues relating to the provision of accommodation.

E. The financing of individuals.

The aim is to provide a readable guide to the many issues which arise in the care of the client in the community with special emphasis on the practical problems and situations which are likely to occur. The law is explained in relation to specific situations which are frequently encountered by professionals. Inevitably any division of the subject area will lead to an artificial treatment of the topic in that there will be overlaps and omissions. The goodwill of the reader is sought in tolerating the cross references which are necessary to avoid repetition of such material.

The decision was taken not to divide the legal issues into client groups, for example mentally ill, learning disabilities, elderly, physically disabled and so on, since services are not necessarily categorised in that way and many professionals work across any such boundaries.

Two major areas of the law, those relating to children and education (except in the context of health care), are omitted. The reason for the omission is simply space. There are sufficient specialist books dealing with these areas to justify excluding them from this text. This has allowed more focused concentration on the issues of community care in the context of health and social services. Midwives have also been omitted from the health professionals considered in Section B, not because they do not have a community role, but because a specific book on midwifery law has just been published which deals more appropriately with issues particularly their concern.

Where possible the emphasis is on practical problems rather than academic niceties. It is a book for the practitioner rather than the lawyer. Where relevant cases have been cited and the facts given since this reveals clearly to the practitioner the extent to which their work is subject to oversight by the courts. To illustrate other problems, not yet the subject of court hearings, situations have been envisaged which are fictional but useful 
in illustrating potential hurdles. They do not represent any living persons.

The actual wording of statutes has been quoted where relevant, and this has been placed in the figures so that the continuity of the text is not destroyed. Those practitioners who are interested in the actual words of the sections concerned can study these. Reference material which should be of assistance to the practitioner is included in the appendices.

The aim is to make the law meaningful to the practitioner who cannot leave all legal knowledge to the lawyer. Practitioners must be aware of the legal framework within which they practice and know at which point they require to bring in the legal experts.

It is apparent that each chapter could be a book in its own right and omissions are inevitable. The book therefore includes a list for further reading confined to books on law. There is also in Appendix 3 limited specialist bibliographies on Health and Safety and HIV/Aids and on Community Care assessments. Such bibliographies, including current Health Circulars and so on, are maintained by major reference libraries and the libraries of educational establishments. The interested reader is referred to these.

In addition in this book a selective list of useful addresses is provided and a glossary to chart a way through the many technical terms. Terminology in relation to the recipient of services, variously called the client, consumer, customer, patient or resident, can cause difficulties and in the main the term 'client' has been used, except in relation to accommodation where the term resident was considered more appropriate.

Finally, the perennial problem of he or she, his or her has been resolved by generally referring to all in the plural or in the feminine gender unless the context is clearly to the contrary. So for 'she' read also 'he' and for 'her' read also 'him'. 


\section{Acknowledgements}

It is impossible to mention all the numerous individuals who have assisted me in the completion of this book. Perhaps it is even invidious to mention some by name. However, I would like to give special thanks to Yvonne Apsitis, Mel Evans, Margaret Griffiths, Marilyn Tickner, Sally Kettle, Penny Llewellyn, Marion Way, Carol Tucker, Peter Williams, Ian Ferris, J. Donnally, M. Goodwin, Joan Harlow, A. Thomas, S. Dando, Margaret Williams, Kathy Hier, Margery Nawaz, Paul Morgan, Barbara Wilson, Richard Rowson and Chris Chaplin. Others to be added are Catherine Cotterill, librarian, Bevan Ashford who assisted in a library search, Tessa Shellens and Peter Edwards who read through the whole manuscript and made extremely helpful suggestions in the initial stages. I accept responsibility, however, for any errors and omissions that remain.

I am grateful to Richenda Milton-Thompson, my editor, for having the persistence to see this project through and acknowledge the considerable debt I owe to Tamsin Bacchus, my copy editor.

Finally, as always, I thank my family and friends for their support and patience and for whom 'community care' has quite a different meaning. 


\section{Abbreviations}

CA Court of Appeal

CHC Community Health Council

CHP Council for Health Professions

COSHH Control of Substances Hazardous to Health

CPN Community Psychiatric Nurse

CPSM Council to the Professions Supplementary to Medicine

CSSD Central Sterile Supply Department

DHA District health authority

DSS Department of Social Security

FHSA Family Health Services Authority

GP General practitioner

GPFH GP fund-holder

HAG Housing Association Grant

HCHS Hospital and community health services

HIV Human Immunodeficiency Virus

HL House of Lords

HSC Health Services Commissioner (Ombudsman)

HSE Health and Safety Executive

JCC Joint Consultative Committee

JP Justice of the Peace

MDU Medical Defence Union

NAA National Assistance Act

NHSME National Health Service Management Executive

PRN As required (of medicines)

QBD Queens Bench Division (of the High Court)

RHA Regional Health Authority

RMO Responsible Medical Officer

RPSGB Royal Pharmaceutical Society of Great Britain.

RSC Rules of the Supreme Court

SNMA Special Needs Management Allowance

SPPA Special Projects Promotional Allowance

SSD Social Services Department

SSI Social Services Inspectorate

UKCC United Kingdom Central Council for Nursing, Midwifery and Health Visiting

WHC Welsh Health Circular 